\title{
Analisis Percepatan Tanah Gempa di Sumatera Menggunakan Jaringan Syaraf Tiruan Metode Backpropagation
}

\author{
Toni Widianto*, Zulfi Abdullah, Dwi Pujiastuti \\ Laboratorium Fisika Bumi, Jurusan Fisika, FMIPA, Universitas Andalas \\ Kampus UNAND Limau Manis, Padang, 25163 \\ *widianto_toni@yahoo.com
}

\begin{abstract}
ABSTRAK
Telah dilakukan penelitian tentang percepatan tanah menggunakan Jaringan Syaraf Tiruan (JST) yang bertujuan untuk menganalisis serta memprediksi percepatan tanah di Sumatera. Penelitian ini menggunakan data percepatan tanah yang direkam dengan accelerograph yang terdapat pada 3 stasiun di Sumatera Barat, yaitu Stasiun Geofisika Padang Panjang (PAPA), Stasiun Meteorologi Ketaping (PATA), dan Stasiun Maritim Teluk Bayur (PATU). Pengolahan data ini menggunakan metode backpropagation. Dalam pengolahan data, dilakukan dengan 2 jenis pembagian data, yaitu pembagian data dengan rasio 50:50, dimana data tahun 2016 dan 2017 digunakan sebagai target uji, selanjutnya pembagian dengan rasio 80:20, dimana data tahun 2017 digunakan sebagai target uji. Setelah dilakukan proses pelatihan dan pengujian, didapatkan bahwa pembagian data dengan rasio 80:20 mendapatkan hasil yang lebih baik daripada pembagian data dengan rasio 50:50. Secara keseluruhan pada proses pengolahan data yang telah dilakukan, dapat disimpulkan bahwa JST tidak mampu memprediksi percepatan tanah di Sumatera, hal ini dikarenakan nilai error yang didapatkan cukup besar.

Kata kunci: percepatan tanah, jaringan syaraf tiruan, backpropagation
\end{abstract}

\section{ABSTRACT}

Have been done a research about ground acceleration using artificial neural network (ANN) that have a goal to analysis and predict ground acceleration in Sumatera. This researh using ground acceleration data that have been recorded by accelerograph that is palced at 3 stations in West Sumatera, that is Padang Panjang Geophysics Station (PAPA), Ketaping Meteorology Station (PATA), Teluk Bayur Maritime Station (PATU). This data was processed by backpropagation methods. In processing data, the data was shared in 2 samples, that is processing data with ratio 50:50, which is data from 2016 and 2017 would be processed as examining target, and ratio 80:20, which is data from 2017 would be processed as examining target. After processing data with training and examining, found that processing data with ratio 80:20 have a better result than data with ratio 50:50. Overall, on processing data that has been done, we can conclude that AAN can not predicted ground acceleration in Sumatra, it is because of error value is quite large.

Keywords: ground acceleration, artificial neural network, backpropagation

\section{PENDAHULUAN}

Gempa bumi merupakan guncangan hebat yang menjalar ke permukaan bumi yang disebabkan oleh gangguan di dalam litosfir. Gangguan ini terjadi karena di dalam lapisan kulit bumi dengan ketebalan $100 \mathrm{~km}$ terjadi akumulasi energi akibat pegeseran kulit bumi itu sendiri. Umumnya gempa bumi disebabkan dari pelepasan energi yang dilepaskan oleh tekanan yang dilakukan lempengan yang bergerak. Semakin lama tekanan akan semakin membesar dan akhirnya mencapai suatu keadaan dimana tekanan tidak dapat ditahan lagi sehingga terjadi gempa bumi, yang energinya menjalar ke berbagai arah (Mustafa, 2010). Sumatera merupakan salah satu daerah yang rawan akan terjadinya gempa bumi. Kondisi ini disebabkan letaknya yang berada pada daerah tumbukan dua lempeng besar, yaitu Lempeng Indo-Australia di bagian selatan dan Lempeng Eurasia di bagian utara yang ditandai dengan terdapatnya pusat-pusat gerakan tektonik di sekitarnya (Hasan dan Santoso, 2014). Gempa bumi menghasilkan nilai percepatan tanah akibat percepatan gelombang yang sampai ke permukaan bumi (Gustian, 2009). Untuk percepatan tanah sendiri terbagi menjadi dua bagian, yaitu percepatan tanah sesaat dan percepatan tanah maksimum (PGA). Percepatan tanah sesaat adalah nilai percepatan tanah pada saat gempa terjadi. Sedangkan PGA adalah nilai percepatan tanah yang terbesar yang pernah terjadi di suatu tempat yang diakibatkan oleh gempa bumi. Semakin besar nilai percepatan tanah yang terjadi di suatu daerah, maka semakin besar resiko dan bahaya gempa bumi yang terjadi (Putri dkk., 2017). 
Penelitian mengenai percepatan tanah maksimum dengan menggunakan perumusan empiris seperti metode Gutenberg-Richter, Murphy-O'Brien, dan Mc.Guirre menggunakan data-data dari parameter gempabumi (Edwiza dan Novita, 2008). Dalam penggunaannya, perumusan empiris sendiri memanfaatkan data-data historis dari kejadian gempa, kemudian dijadikan dalam bentuk sebuah permodelan, sehingga pengolahan data dapat dilakukan dengan perumusan matematis. Namun pada jaringan syaraf tiruan, dalam pengolahannya tidak perlu melakukan permodelan dalam pengolahan data, sehingga lebih praktis dibanding dengan perumusan empiris, tetapi jaringan syaraf tiruan sendiri membutuhkan pola agar hasil data yang diolah mendapatkan hasil yang akurat.

Jaringan Syaraf Tiruan (JST) merupakan sistem pemrosesan informasi yang memiliki karakteristik mirip dengan jaringan syaraf biologi. JST mampu mengenali kejadian dengan berbasis pada data masa lalu. Data masa lalu akan dipelajari oleh JST sehingga mempunyai kemampuan untuk memberi keputusan data yang belum pernah dipelajari (Hermawan, 2006). Dalam pengaplikasiannya, JST telah banyak digunakan sebagai peramalan dalam berbagai kasus dengan mengenali pola-pola kejadian yang telah terjadi pada masa lalu, seperti prediksi terhadap curah hujan, konsumsi bahan bakar, pengingkatan permintaan konsumen, dan sebagainya. Pada kasus gempa bumi, JST biasa digunakan untuk memprediksi nilai percepatan tanah sesaat pada suatu daerah ketika terjadi gempabumi, dengan memanfaatkan data percepatan tanah yang direkam oleh accelerograph pada stasiun atau bangunan. Adapun maksud dari prediksi percepatan tanah sendiri bertujuan untuk mengetahui dan memprediksi nilai percepatan tanah sesaat pada suatu daerah ketika terjadi gempa bumi, sehingga hasil prediksi ini dapat digunakan oleh peneliti dan pemerintah setempat sebagai salah satu langkah dalam mitigasi bencana gempabumi.

Gunaydin K., dan Gunaydin A., (2008) pernah memanfaatkan JST untuk memprediksi PGA menggunakan 3 metode, yaitu metode feed-forward backpropagation, metode radial basis function, dan metode generalized regression neural networks. Pada penelitian tersebut didapatkan hasil bahwa JST dapat digunakan untuk memperoleh model perepatan tanah maksimum di Northwestern Turkey dengan menggunakan data latih dan data uji yang didapatkan. Thomas dkk., (2013) juga pernah memanfaatkan JST untuk melakukan prediksi PGA menggunakan metode feed forward, metode backpropagation, dan metode radial bias network. Dari penelitian yang dilakukan, didapatkan hasil bahwa JST dapat digunakan untuk memprediksi PGA dengan menghubungkan antara hasil prediksi dengan data sebenarnya.

Penelitian ini akan memanfaatkan JST metode backpropagation untuk mengenali pola percepatan tanah di Pulau Sumatera serta melihat kemampuan JST dalam memprediksi PGA di Sumatera dibanding menggunakan perumahan empiris lainnya. Penelitian ini menggunakan data accelerograph yang terdapat di Sumatera pada tahun 2012 hingga 2017. Adapun manfaat dari penelitian ini adalah untuk mengetahui pola percepatan tanah dan nilai percepatan tanah di Sumatera, sehingga dapat menjadi referensi bagi peneliti dan masyarakat umum untuk mitigasi dan meminimalisir efek negatif gempa bumi, serta alternatif mengurangi dampak gempa bumi dibanding dengan perumusan empiris.

\section{METODE}

Penelitian ini dilakukan di Laboratorium Fisika Bumi, Jurusan Fisika, Fakultas Matematika dan Ilmu Pengetahuan Alam. Data sekunder percepatan tanah didapatkan dari Stasiun Pusat Badan Meteorologi Klimatologi dan Geofisika, Jakarta. Data percepatan tanah merupakan data percepatan yang direkam oleh accelerograph pada Stasiun Geofisika Padang Panjang (PAPA), Stasiun Meteorologi Ketaping (PATA), dan Stasiun Maritim Teluk Bayur (PATU). Data percepatan tanah yang digunakan pada penelitian ini merupakan data percepatan tanah gempa yang terjadi di Pulau Sumatera pada tahun 2012 hingga tahun 2017. Selanjutnya dilakukan karakteristik data penelitian dengan memisahkan dan mengelompokkan data-data gempa berdasarkan data yang terekam pada masing-masing stasiun.

Setelah didapatkan karakteristik dari data, selanjutnya dilakukan proses pemisahan data data latih, taget latih, data uji, dan target uji. Pemisahan data dilakukan dengan menggunakan dua rasio, yaitu rasio 50:50 dan rasio 80:20. Pada rasio 50:50, data percepatan tanah yang akan datang diprediksi berdasarkan data kejadian gempa 24 sebelumnya. Dimana data tahun 2012 
hingga data tahun 2013 merupakan data latih, dan data tahun 2014 hingga 2015 merupakan target latih. Selanjutnya data tahun 2014 hingga data tahun 2015 digunakan sebagai data uji, dan data tahun 2016 hingga tahun 2017 merupakan target dari data uji. Pada rasio 80:20, data tahun selanjutnya diprediksi berdasarkan kejadian gempa 12 bulan sebelumnya, dimana data tahun 2012 hingga 2015 merupakan data latih, dan data tahun 2013 hingga tahun 2016 merupakan target dari data latih. Selanjutnya data pada tahun 2016 merupakan data uji, dan data pada tahun 2017 merupakan target dari data uji.

Setelah dilakukan pembagian data, selanjutnya dilakukan pengolahan data menggunakan jaringan syaraf tiruan lapisan jamak (multi layer network). Pada proses pelatihan, akan dilakukan proses input nilai bobot secara trial dan error. Apabila hasil yang didapatkan sesuai dengan target maka akan dilanjutkan dengan proses pengujian, namun jika hasil yang didapatkan tidak sesuai dengan target maka akan dilakukan proses input nilai bobot hingga didapatkan hasil yang terbaik. Pada proses pengujian, apabila hasil yang didapatkan tidak sesuai dengan yang diharapkan, maka akan diulang lagi penentuan struktur dari jaringan syarah tiruan, namun jika hasil yang didapatkan sesuai dengan yang diharapkan, maka akan dilanjutkan dengan implementasi jaringan syaraf tiruan.

\section{HASIL DAN DISKUSI}

\subsection{Pengolahan Data dengan Rasio 50:50}

\subsubsection{Stasiun Geofisika Padang Panjang}

Pada Gambar 1(a) terlihat perbandingan grafik keluaran JST dengan grafik target proses pelatihan pada Stasiun Geofisika Padang Panjang. Dari grafik terlihat bahwa pada proses pelatihan data telah didapatkan data terbaik dengan nilai error 0,000099689 . Selanjutnya pada proses pengujian seperti pada Gambar 1(b), terlihat grafik keluaran JST tidak sesuai dengan grafik data target. Dengan nilai error yang didapatkan pada proses pengujian mencapai 0,8688 , dapat disimpulkan bahwa hasil keluaran JST pada proses pengujian menunjukkan hasil yang tidak akurat.

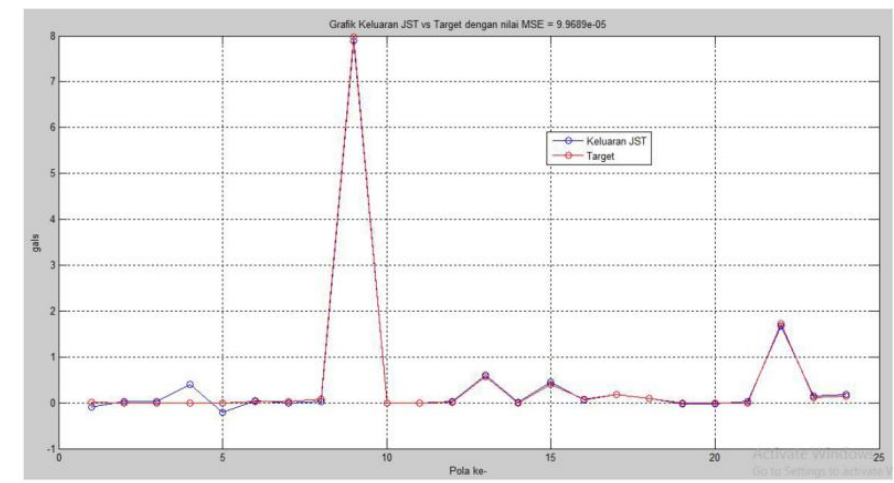

(a)

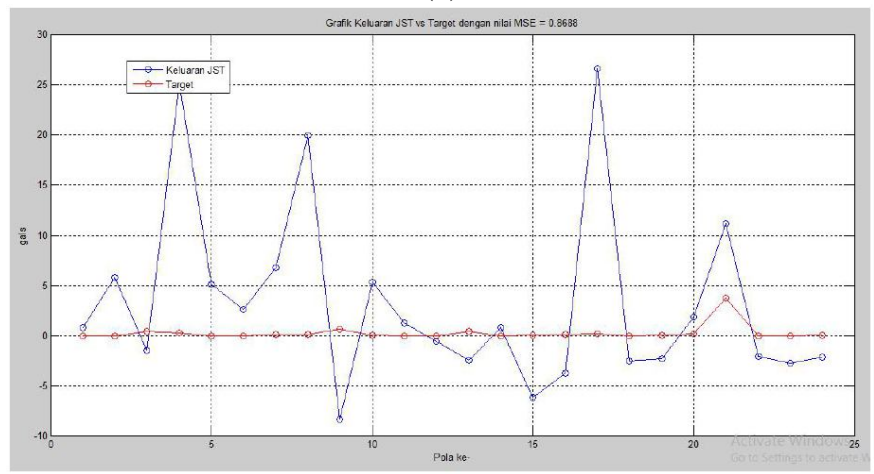

(b)

Gambar 1 (a) Grafik keluaran JST (biru) vs grafik target (merah) Stasiun Geofisika Padang Panjang pada proses pelatiha (b) Grafik keluaran JST (biru) vs grafik target (merah) Stasiun Geofisika Padang Panjang pada proses pengujian 


\subsubsection{Stasiun Meteorologi Ketaping}

Gambar 2(a) merupakan hasil perbandingan grafik keluaran JST dengan grafik target pada Stasiun Meteorologi Ketaping. Dari grafik tersebut dapat kita lihat bahwa, pada proses pelatihan terlihat bahwa grafik keluaran JST hampir sesuai dengan grafik yang sebenarnya, hal ini menunjukkan bahwa data terbaik telah didapatkan dengan nilai error yang yaitu 0,0000999. Selanjutnya pada proses pengujian seperti yang terlihat pada Gambar 2(b), terlihat hasil keluaran JST tidak sesuai dengan grafik yang target. Dengan nilai error yang didapatkan mencapai 0,070927 juga menunjukkan bahwa grafik keluaran JST tidak akurat.

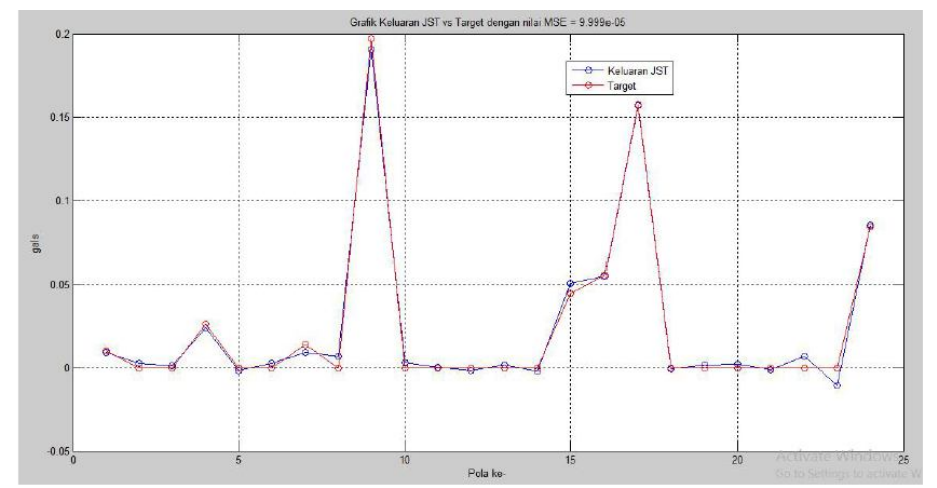

(a)

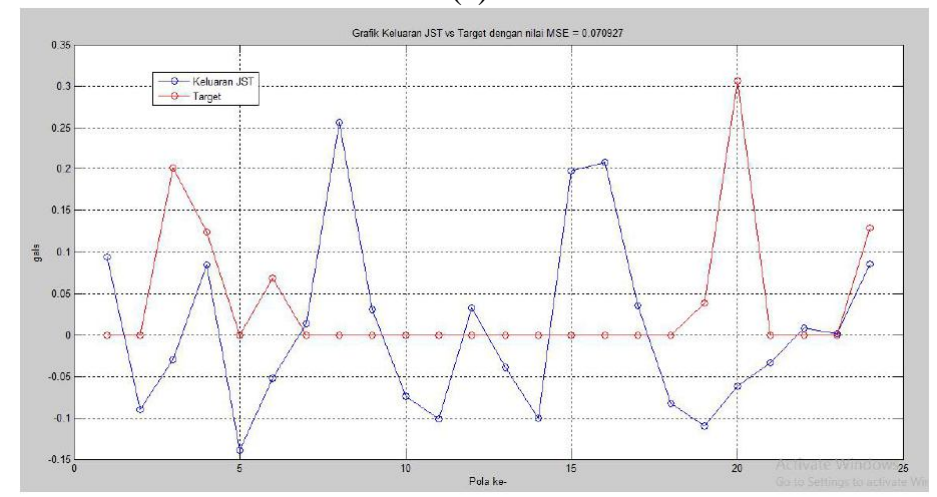

(b)

Gambar 2 (a) Grafik keluaran JST (biru) vs grafik target (merah) Stasiun Meteorologi

Ketaping pada proses pelatihan (b) Grafik keluaran JST (biru) vs grafik target (merah)

Stasiun Meterologi Ketaping pada proses pengujian

\subsubsection{Stasiun Maritim Teluk Bayur}

Pada Gambar 3(a) terlihat perbandingan grafik keluaran JST vs grafik target pada proses pelatihan Stasiun Maritim Teluk Bayur, dimana hasil yang didapatkan menunjukkan bahwa pada proses pelatihan JST, telah didapatkan data terbaik dengan nilai error sebesar 0,000099958. Pada Gambar 3(b) terlihat grafik keluaran JST vs grafik target pada proses pengujian Stasiun Maritim Teluk Bayur, dimana grafik yang didapatkan tidak sesuai dengan grafik target. Dengan nilai error yang didapatkan sebesar 0,54376, dapat disimpulkan bahwa JST tidak mampu memprediksi data percepatan dengan akurat. 


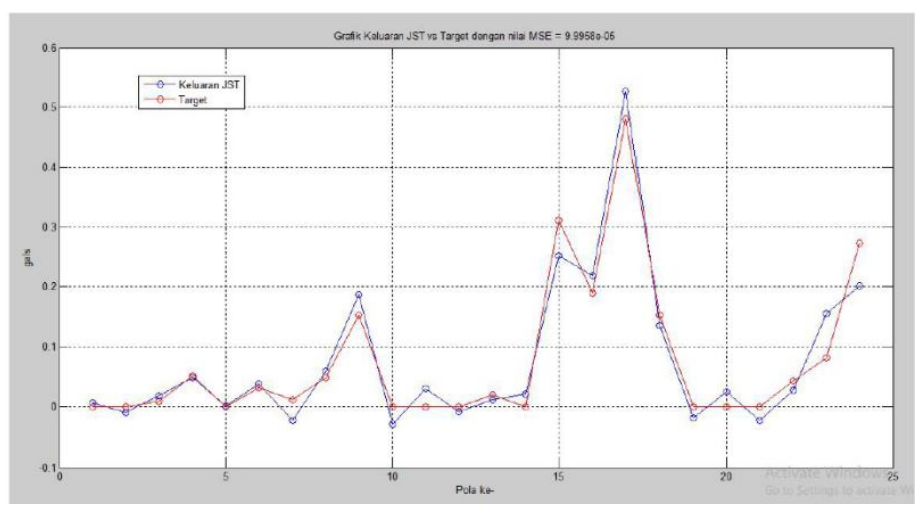

(a)

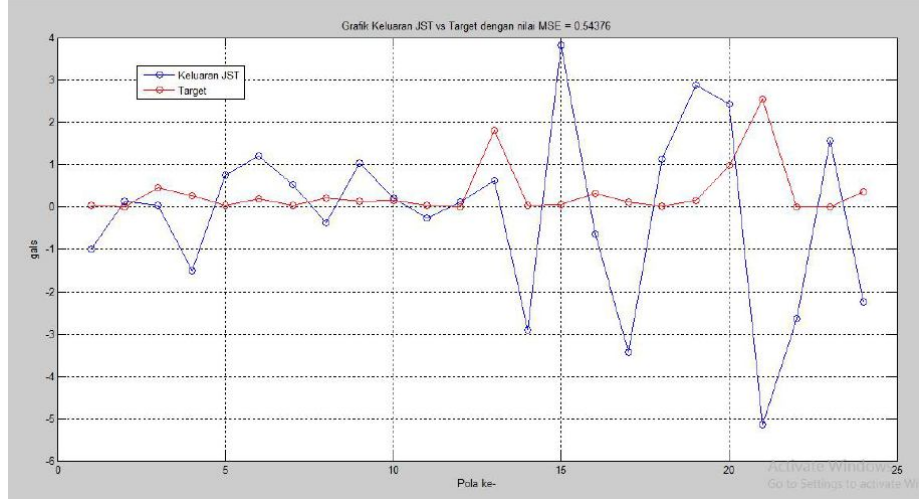

(b)

Gambar 3 (a) Grafik keluaran JST (biru) vs grafik target (merah) Stasiun Maritim Teluk Bayur pada proses pelatihan (b) Grafik keluaran JST (biru) vs grafik target (biru) Stasiun Maritim Teluk Bayur pada proses pengujian

\subsection{Pengolahan Data dengan Rasio 80:20}

\subsubsection{Stasiun Geofisika Padang Panjang}

Pada Gambar 4(a) terlihat grafik keluaran JST dengan grafik target Stasiun Geofisika Padang Panjang pada proses pelatihan. Dari grafik terlihat perbandingan keluaran JST dan target memiliki nilai error yang mencapai 0,0031033, sehingga dapat disimpulkan bahwa JST telah mendapatkan data terbaik pada iterasi tersebut. Pada Gambar 4(b) terlihat perbandingan grafik keluaran JST dengan grafik target pada proses pengujian. Dari grafik terlihat bahwa keluaran JST tidak sesuai dengan yang diharapkan, dengan nilai error mencapai 0,40641 dapat disimpulkan bahwa JST tidak mampu memprediksi data dengan baik.

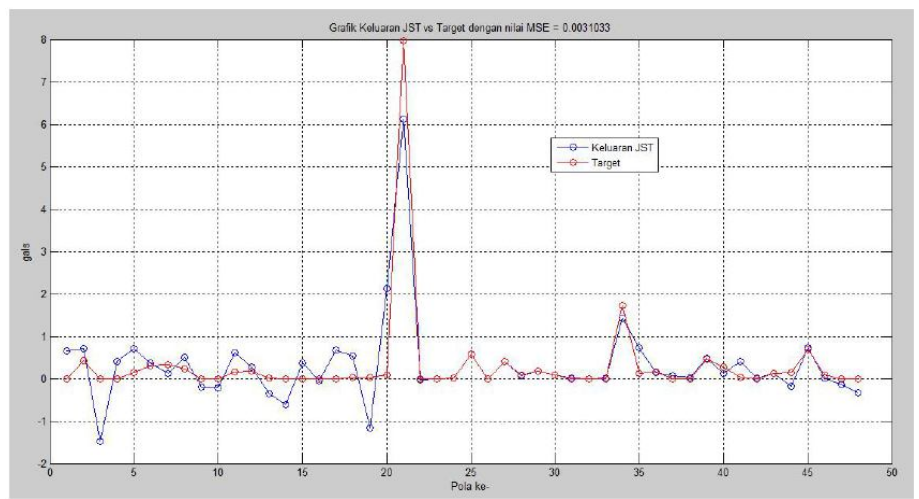

(a) 




(b)

Gambar 4 (a) Grafik keluaran JST (biru) vs grafik target (merah) Stasiun Geofisika Padang Panjang pada proses pelatihan (b) Grafik keluaran JST (biru) vs grafik target (merah) Stasiun Geofisika Padang Panjang pada proses pelatihan

\subsubsection{Stasiun Meteorologi Ketaping}

Pada Gambar 5(a) terlihat grafik perbandingan keluaran JST dengan grafik target pada proses pelatihan Stasiun Meteorologi Ketaping. Dari grafik proses pelatihan terlihat bahwa JST telah mendapatkan data terbaik dengan nilai error yang didapatkan mencapai 0,00062967. Namun pada Gambar 5(b) terlihat grafik keluaran JST dengan grafik target Stasiun Meteorologi Ketaping pada proses pengujian. Dari grafik terlihat bahwa JST tidak mampu memprediksi grafik target dengan baik, hal ini juga terlihat dari nilai error yang didapatkan sebesar 0,087885, menunjukkan bahwa grafik keluaran JST menunjukkan hasil yang tidak akurat.

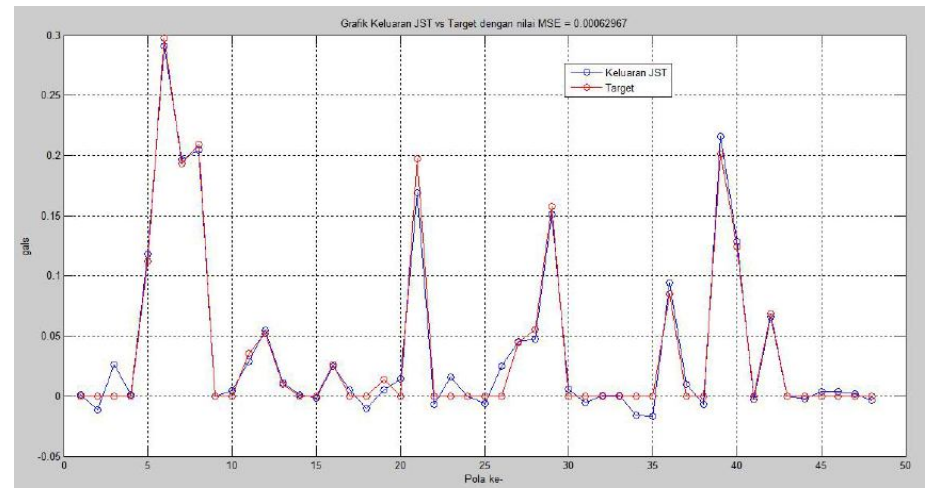

(a)

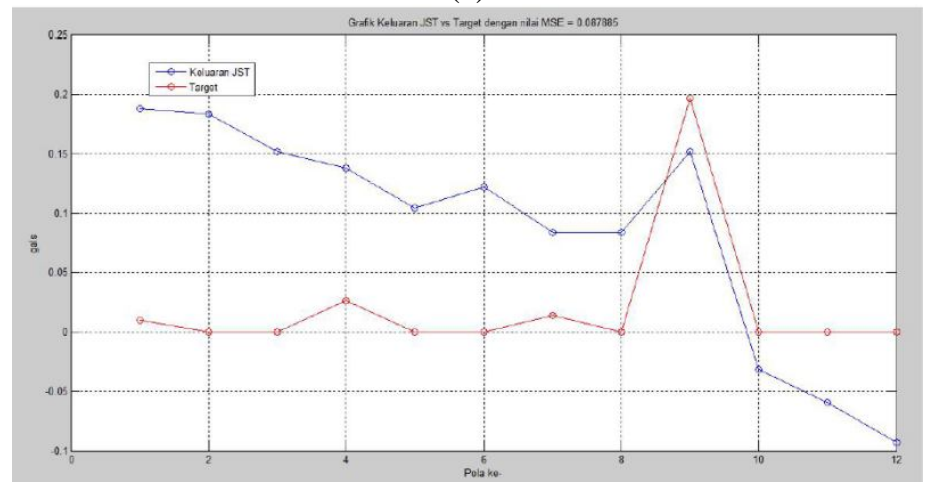

(b)

Gambar 5 (a) Grafik keluaran JST (biru) vs grafik target (merah) Stasiun Meteorologi Ketaping pada proses pelatihan (b) Grafik keluaran JST (biru) vs grafik target (merah) Stasiun Meteorologi Ketaping pada proses pengujian 


\subsubsection{Stasiun Maritim Teluk Bayur}

Pada Gambar 6(a) terlihat grafik keluaran JST dengan grafik target Stasiun Maritim Teluk Bayur pada proses pelatihan. Dari gambar menunjukkan bahwa JST telah mendapatkan data terbaik pada proses pelatihan, terlihat dari nilai error yang didapatkan mencapai 0,0029338. Namun pada Gambar 6(b) terlihat grafik keluaran JST dengan grafik target Stasiun Maritim Teluk Bayur pada proses pengujian. Dari grafik terlihat bahwa hasil keluaran JST tidak sesuai dengan grafik yang diharapkan. Nilai error yang didapatkan pada proses pengujian ini mencapai 0,0329338 menunjukkan bahwa hasil keluaran JST tidak akurat.

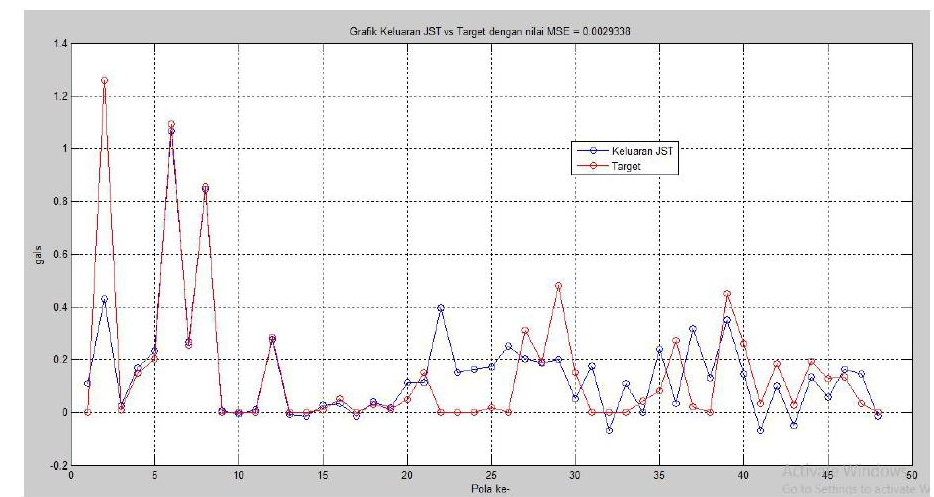

(a)

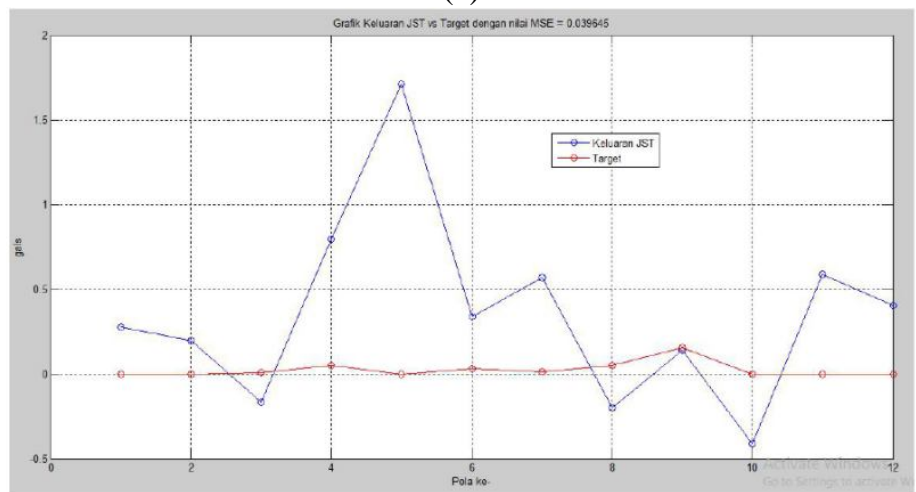

(b)

Gambar 6 (a) Grafik keluaran JST (biru) vs grafik target (merah) Stasiun Maritim Teluk Bayur pada proses pelatihan (b) Grafik keluaran JST (biru) vs grafik target (merah) Stasiun Maritim Teluk Bayur pada proses pengujian

\subsection{Hasil Percepatan Tanah dan Jaringan Syaraf Tiruan}

Pada proses pelatihan dan pengujian, hasil yang didapatkan bervariasi dikarenakan data latih dan data uji yang digunakan juga bervariasi. Hal ini dapat dilihat dari data percepatan tanah yang terekam pada accelerograph masing-masing stasiun. Data yang digunakan juga terjadi secara acak dan tidak kontinu. Sehingga hasil yang didapatkan tidak sesuai dengan yang diharapkan. Selain itu, hasil yang didapatkan juga dipengaruhi oleh sumber gempa yang berasal dari berbagai segmen gempa yang ada di Sumatera.

\section{KESIMPULAN}

Dari penelitian yang telah dilakukan, dapat disimpulkan bahwa pembagian variasi dalam pengolahan data mempengaruhi hasil dari proses pelatihan dan pengujian data. Pada penelitian ini, penggunaan JST metode backpropagation tidak mampu memprediksi nilai dari percepatan tanah dengan baik. Hal ini dikarenakan data yang digunakan pada penelitian ini terlalu singkat dan juga dikarenakan sumber gempa juga berasal dari berbagai segmen gempa yang ada di Sumatera, sehingga JST tidak mampu mengenali pola percepatan tanah dan didapatkan hasil bahwa JST tidak dapat memprediksi percepatan tanah yang terdapat di Sumatera. 


\section{DAFTAR PUSTAKA}

Edwiza D., dan Novita, "Pemetaan Percepatan Tanah Maksimum dan Intensitas Seismik Kota Padang Panjang Menggunakan Metode Kana”, Jurnal Geofisika, 1(2), 2008, hal. 8-12.

Gunaydin K., dan Gunaydin A., 2008, Peak Ground Acceleration Prediction by Artificial Neural Networks for Northwestern Turkey, Artikel Ilmiah, Hindawi Publishing Corporations.

Gustian A., 2009, Analisa Percepatan Tanah Maksimum Wilayah Pulau Sumatera dan Sekitarnya, Akademi Meteorologi dan Geofisika, Jakarta.

Hasan M.M., dan Santosa B.J., Analisa Pola Bidang Sesar pada Zona Subduksi di Wilayah Sumatera Barat dari Event Gempa pada Tahun 2013, Jurnal Sains dan Seni ITS, 1(3), 2012, hal. 11-14.

Hermawan A., 2006, Jaringan Syaraf Tiruan, Andi, Yogyakarta.

Mustafa B., Analisis Gempa Nias dan Gempa Sumatera Barat dan Kesamaannya Yang Tidak Menimbulkan Tsunami, Jurnal Ilmu Fisika Universitas Andalas, 1(2), 2010, hal. 4450.

Putri A.R., Purwanto M.S., Widodo A., Identifikasi Percepatan Tanah Maksimum (PGA) dan Kerentanan Tanah Menggunakan Metode Mikrometer I Jalur Sesar Kendeng, Jurnal Geosaintek, 3(2), 2017, hal. 107-114.

Thomas S., Pillai G.N., Pal K., Zuhair, Prediction of Peak Ground Acceleration (PGA) Using Artificial Neural Networks, Proc. of Int. Conf. on Advances in Computer Science, AETACS, 2013, hal. 276-276. 